\title{
Respirometrie - soos toegepas op terrestriële en akwatiese invertebrate
}

\author{
W. J. van Aardt \\ Departement Dierkunde, Potchefstroomse Universiteit vir C.H.O., Potchefstroom 2520
}

Onrvang 26 Fobruarie 1990; aunvar 20 Scptember 1990

\section{UITTREKSEL}

'n Oorsig word gegee van apparatuur en tegnieke wat gebruik word om die suurstofverbruikskoers $\left(\dot{M} \mathrm{O}_{2}\right)$ van terrestriële en akwatiese invertebrate te meet. Die manometriese metode (veral konstante drukrespirometrie) is in die verlede baie gebruik om $\mathrm{MO}_{2}$ by invertebrate te meet. Tans word hierdie metode nog steeds suksesvol gebruik vir veral invertebrate wat kleiner as I mg in lewende massa is. Die meer resente elektrochemiese metodes bied die voordeel dat metings oor baie langer tye kan geskied, omdat die apparatuur makliker geoutomatiseerd gemaak kan word. Dit het veral die metings van $\mathrm{MO}_{2}$ by akwatiese diere baie bevorder. Hiervoor is die polarografiese suurstofsensor gebruik. Met die onlangse uitvinding van die sirkoniumsuurstofsensor kon ook noukeurige metings van die $\mathrm{MO}_{2}$ van groter terrestriële invertebrate met die hulp van hierdie elektrochemiese apparatuur verkry word.

\section{ABSTRACT}

\section{Respirometry - as applied to terrestrial and aquatic invertebrates}

A review is presented of the apparatus and techniques used to determine the oxygen consumption rate (M) $\left.\mathrm{O}_{2}\right)$ of terrestrial and aquatic invertebrates. The classic manometric method (especially constant pressure respirometry) has been extensively used in the past to measure $\mathrm{MO}_{2}$. At present this method is still being used with success for small invertebrates weighing less than $1 \mathrm{mg}$ in live weight. The more modern electrochemical techniques have the advantage that measurements can be made over longer time intervals because these instruments are better suited to automation. $\mathrm{MO}_{2}$ measurements were first performed on aquatic animals with polarographic oxygen sensors. After the invention of the zirkonium oxygen sensor it is now possible to make accurate measurements of $\mathrm{MO}_{2}$ on bigger terrestrial invertebrates.

Sedert die eerste beskrywing van 'n respirometer ${ }^{1.2}$ het hierdie meetmetode in die biologie, en later in die biochemie, groot ontwikkelings ondergaan. Daar is nie net beter en dus noukeuriger meetmetodes ontwikkel nie, maar is ook beter materiale gebruik om bestaande respirometers eenvoudiger, betroubaarder en soms goedkoper te maak.

'n Opvallende aspek in die ontwikkeling van die respirometrie is dat die meeste navorsers hulle eie respirometers bou. Dit geld vir respirometers wat werk op sowel manometriese beginsels ${ }^{3}$ as op die beginsel van die polarografiese suurstofelektrode. ${ }^{4}$ Met die ontwikkeling van die heel nuutste sensors, soos die sirkoniumsensor, ${ }^{5}$ kan noukeurige metings van suurstofverbruik van relatief kleiner lugasemhalers oor lang periodes gemaak word.

In hierdic oorsig sal spesiaal aandag gegee word aan die werksbeginsels van respirometers wat gebruik word vir akwatiese en terrestriële invertebrata.

\section{A. MANOMETRIESE METODES}

\section{Konstante drukrespirometrie: Beginsels}

Wanneer suurstof deur die dier, (D), verbruik word en $\mathrm{KOH}$ (K) die $\mathrm{CO}_{2}$ chemies bind, kan die druk in 'n geslote stelsel verminder. Die druk in die stelsel, soos waargeneem op die manometer (M), kan egter konstant gehou word indien 'n kompensasiekamer (A) in hierdie geslote stelsel ingebou word (fig. 1). Die verandering in gasvolume van (2) na (1) kan gebruik word om die hoeveelheid gas wat opgeneem word of die hoeveelheid gas wat afgegee word, te meet.
Met hierdie respirometer word gewoonlik suurstof wat as gas deur diere opgeneem word, gemeet. Maar dit kan ook koolstofdioksied meet wat deur plante en fungi opgeneem word ${ }^{6}$ as koolstofdioksied binne die geslote stesel van die respirometer aanwesig is.

Hoewel Winterstein' die eerste keer hierdie tipe respirometer beskryf en gebruik het, was dit Scholander ${ }^{78,9}$ wat die meeste ontwikkelingswerk aan hierdie tipe respirometers gedoen het. Soms word hierdie respirometers ook Scholanderrespirometers genoem. 'n Herontwerpte en kompakte konstante drukrespirometer wat hulle weer later verbeter het, ${ }^{10}$ is deur Scholander et al" beskryf.

'n Opvallende kenmerk van die nuwe ontwerp is dat die kompensasiekamer rondom die manometer geplaas is (fig. 2). Om die respirometer te laat werk word $20 \% \mathrm{KOH}$ op

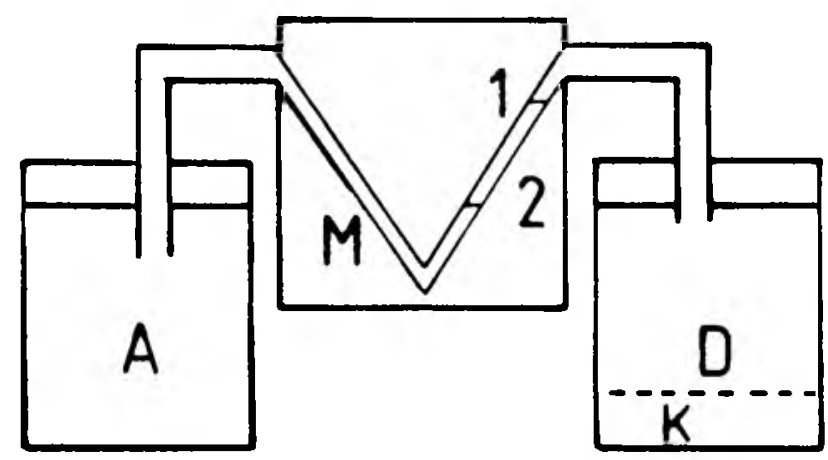

FIGUUR l: Werksbeginsel van 'n konstante drukrespirometer $A$, drukkompensasiekamer. $D$, dierekamer of respirasiekamer. $\mathrm{K}$, KOH-oplossing. M, manometer. 
'n stukkie filtreerpapier in bakkie B geplaas. Die respirometer word in 'n waterbad met deursigtige glaswande geplaas sodat slegs draaiprop $\mathrm{C}$ en stafie $\mathrm{E}$ bo die wateroppervlak uitsteek.

As die respirasie van ' $n$ akwatiese dier in respirasiekamer A gemeet word, dan moet die hele respirometer heen en weer geskud word sodat gasse $\left(\mathrm{CO}_{2}\right.$ vir diere, $\mathrm{O}_{2}$ vir plante) makliker uit die water in die lugruimte van die respirasiekamer kan uitdiffundeer. Na temperatuurewewig, van een uur, word die draaiprop (C) $180^{\circ}$ gedraai vanaf die posisie soos op die figuur angetoon. Hierdeur word die kompensasiekamer, (D) geisoleer van die respirasiekamer (A). Die stafie (E) word op of af gedruk om sodoende manometervloeistof $(F)$ op die verwysingstrepie $(G)$ van die kapillêrbuisie $(\mathrm{H})$ te bring. Die gasvolume wat opgeneem of afgegee word, kan gemeet word deur die stafie op of af te laat skuif sodat die manometervloeistof weer na die verwysingstrepie teruggebring kan word. Die deursnee van die stafie is die enigste konstante wat benodig word om die apparaat te yk. Die respirometer wat deur Scho-

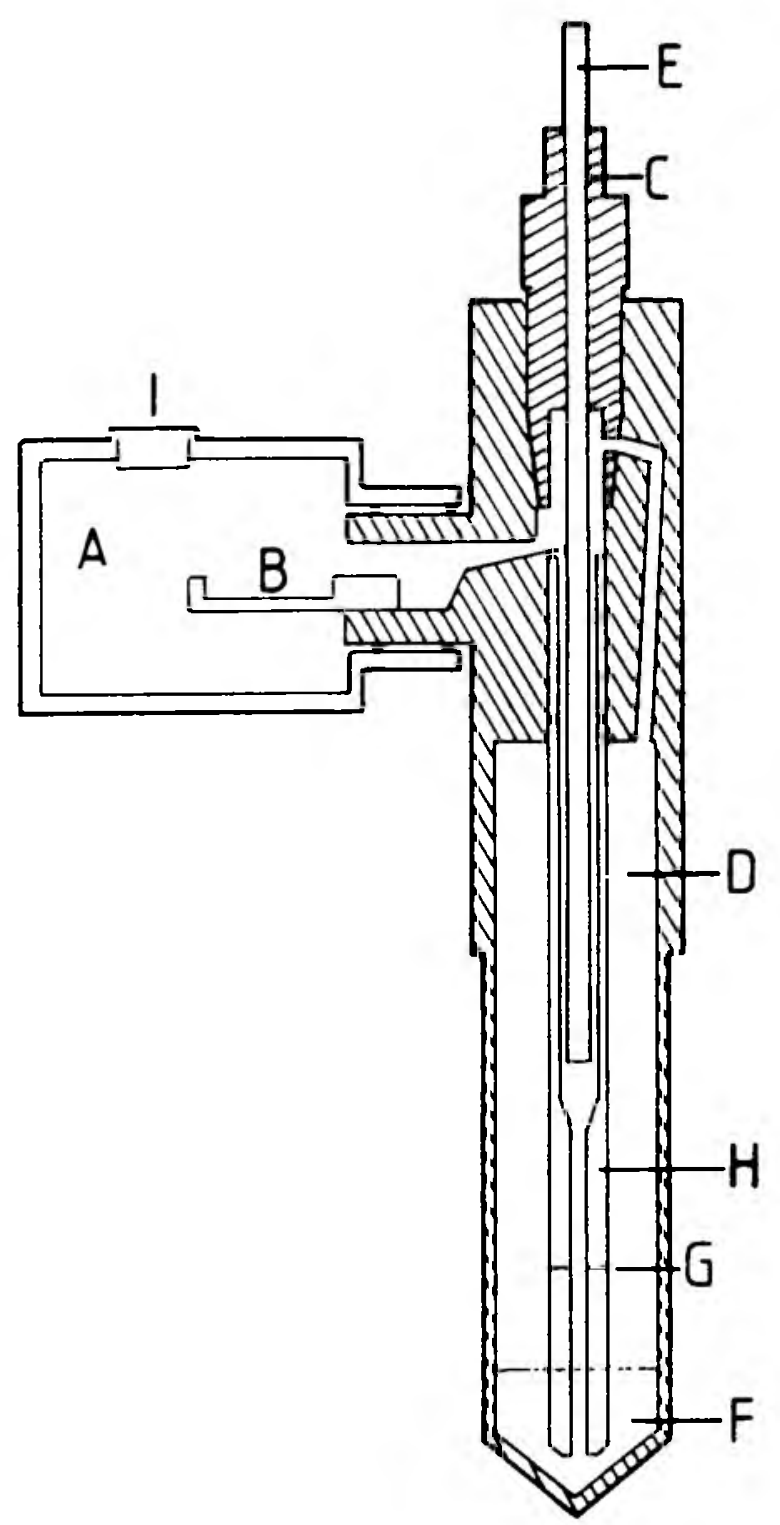

FIGUUR 2: 'n Scholanderrespirometer waarvan die drukkompensasiekamer, $D$, rondom die manometer gebou is. Stafie E word gebruik om die manometervloeistof weer tot vlak $G$ te bring. Besonderhede word in die teks gevind. lander vervaardig is, het ' $\mathrm{n}$ stafiedeursnee wat $7,87 \mathrm{~mm}^{3}$ volume verplaas vir $1 \mathrm{~mm}$ beweging van die stafie. Afsluitvlakke word bewerkstellig met $\mathrm{O}$-ringe van neopreen, terwyl die konusvormige draaistopper van perspeks gemaak is. 'n Silikoonrubberseptum (I) kan op die wand van die respirasiekamer aangebring word, waardeur gasse bygevoeg of verwyder kan word.

Kort nadat hierdie respirometer kommersieel vervaardig is, het Gilson'2 'n vereenvoudigde konstante drukrespirometer op die mark gebring wat so suksesvol was dat die meeste respirometers vandag van hierdie tipe is (fig. 3 ). Die manometers is van 'n spesiale plastiek (Lexan) gemaak en is bo die waterbad se watervlak geplaas. Die een arm van 'n serie van manometers is in verbinding met 'n gemeenskaplike kompensasiekamer deur 'n veelvuldige koppelstuk (A). Die volume van kompensasiekamer (F) behoort 2 keer die volume te wees van die volumes van al die respirasiekamers $(\mathrm{R})$ tesame, wat in gebruik is. ' $\mathrm{n}$ Groot voordeel van die Gilsonrespirometer is dat die aflees van elke respirometer digitaal (fig. 3), verdeel in mikrolitereenhede, is. Dit word bewerkstellig met behulp van 'n mikrometer met 'n plastiekstaaf wat in- en uitgedraai word sodat maksimaal $500 \mu \mathrm{l}$ in volume verplaas word. 'n Verdere voordeel is dat die manometers staties bly, terwyl die bewegende respirasiekamers met hoëkwaliteit- dikwandige tygonbuise (E) (met 'n kapillêre boor) verbind word. Hierdeur word diffusie van gasse beperk. As die gas binne die tygonbuis ongeveer dieselfde konsentrasie is as dié van byvoorbeeld lug, sal diffusie van 'n gas na buite of binne nie meetbare veranderinge veroorsaak nie. Is die gas in die buise egter byvoorbeeld honderd persent $\mathrm{O}_{2}$, sal die diffusie van $\mathrm{O}_{2}$ deur die wand so groot wees dat meetbare veranderinge in die opnamekoers van $\mathrm{O}_{2}$ sal plaasvind. Om dit te oorbrug is dit noodsaaklik om, saam met die kompensasiekamer en respirasiekamers (fig. 3), ook 'n kontrolekamer in die stelsel te voeg sonder 'n respirerende dier of biologiese materiaal. Hierdeur kan die nodige korreksies aangebring word vir die diffusie deur die buiswande.

Die hoeveelheid gasverandering wat deur die mikrometer gemeet word, moet verwerk word na standaardtemperatuur, lugdruk en droë gas (STDD) sodat die waardes vergelyk kan word met derglike waardes by ander laboratoria.

$$
\begin{aligned}
& \mu \text { l gas opgeneem of afgegee by (STDD) per uur } \\
& =\frac{273}{\mathrm{~T}} \times \frac{\left(\mathrm{P}-\mathrm{P}_{\mathrm{H}_{2} \mathrm{O}}\right)}{760} \times \mathrm{Vg}
\end{aligned}
$$

waar: Vg die hoeveelheid gas $(\mu \mathrm{l})$ is wat per uur opgeneem (afgegee) is; $T$ die absolute temperatuur waarby die eksperiment uitgevoer is; $\mathrm{P}-\mathbf{P}_{\mathrm{H}_{2} \mathrm{O}}$ die barometerdruk waartydens die metinge gedoen is, minus die dampdruk van water; en 760 die barometerdruk by seespieël in $\mathrm{mmHg}$ is.

Daar is geargumenteer dat die akkuraatheid van gasopname (of afglfte) beïnvloed word as die mikrometer met sy suier en gasvolume by kamertemperatuur gehou word. As die temperatuur toeneem, sal die gas in die suierruimte uitsit en sodoende die lesings beïnvloed. Om dit te verhoed is konstante drukrespirometers so ontwerp dat daardie deel van die mikrometer wat die suier en gasvolume bevat, onder water gehou word (kyk stippellyne $x$ van fig. 3).

'n Nadeel van konstante drukrespirometers wat 'n invloed op die noukeurigheid van die metings uitoefen, is die feit 


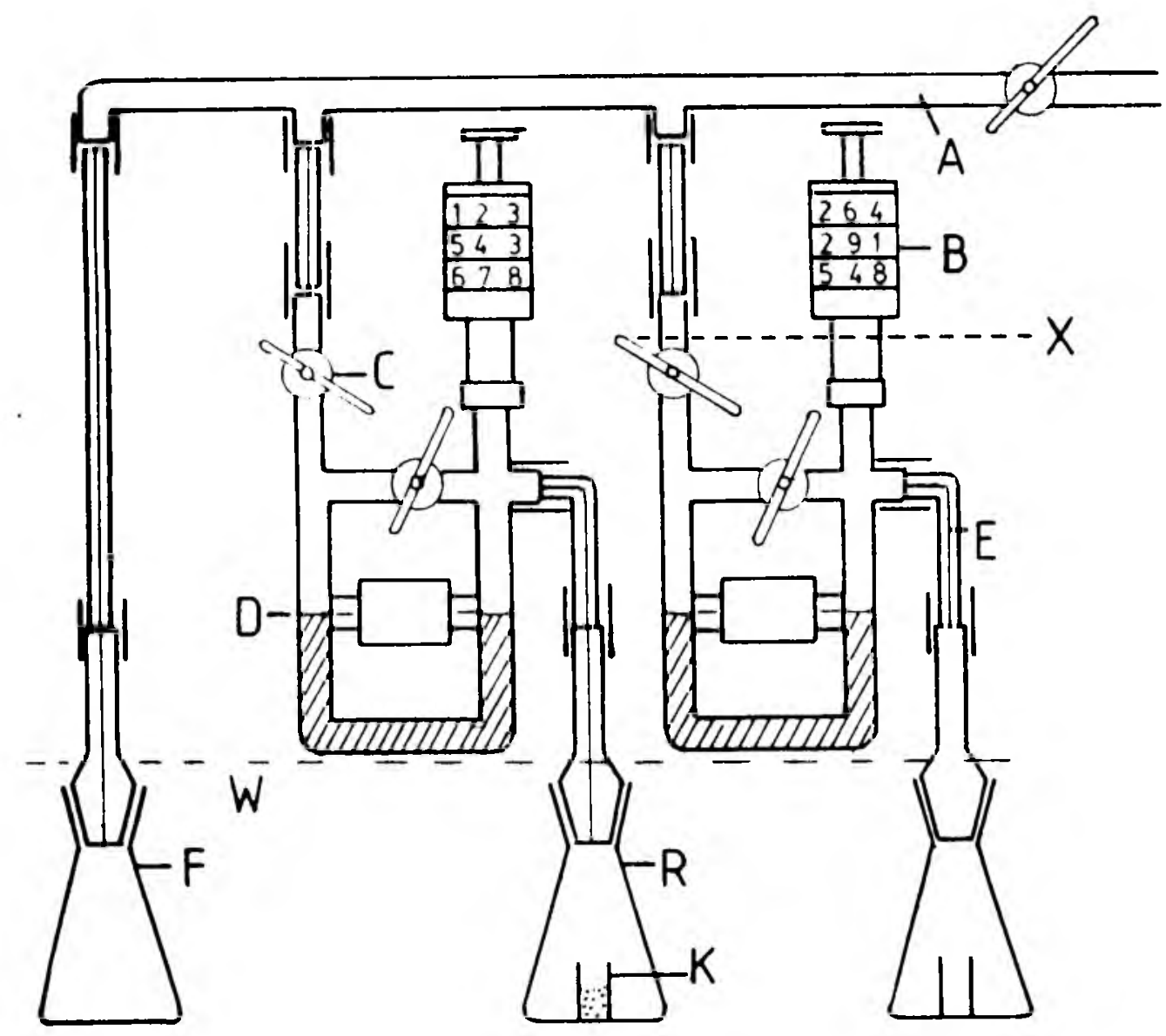

FIGUUR 3: Die konstantedrukrespirometer van Gilson. A, glaskoppelstuk. B, mikrometer. C, kraantjie. D, manometerindeks. $R$, respirasiekamer. $K, 15 \%$ KOH-oplossing. $F$, drukkompensasiekamer. $W$, watervlak. $X$, watervlak van sommige Gilsonrespirometers.

dat die gassamestelling in die dierekamer of respirasiekamer kan verander wanneer byvoorbeeld suurstof deur 'n dier opgeneem word, en dit nie weer deur dieselfde volume suiwer suurstof aangevul word nie. As die gemetaboliseerde gas nie periodiek aangevul word nie, kan, in die geval van aerobiese respirasie by diere, die stikstofkonsentrasie in die dierekamer te hoog styg. Daarom word suiwer suurstof en nie lug nie, periodiek gebruik om die manometer weer tot sy oorspronklike stand of druk in te stel. Vir baie noukeurige metinge word aanbeveel dat die korreksiekonstantes soos beskryf ${ }^{13}$ gebruik word. Die Gilson-konstantedrukrespirometer is verder verbeter deurdat die manometerveranderinge deurlopend op 'n penregistreerder geregistreer word. By die registrerende Gilsonrespirometer word die manometervloeistof na die nulpuntposisie gebring deur 'n servostelsel en nie deur die hand van die eksperimenteerder nie. As suurtof deur die dier opgeneem word, beweeg die manometervloeistof na benede. Hierdie beweging word waargeneem deur 'n ligsensitiewe resistor, sodat die servomeganisme die suier elektries van die mikrometer na benede laat beweeg om vir hierdie verandering te kompenseer. Die grootste voordeel van 'n registrerende respirometer is dat metings aaneenlopend en oor baie lang periodes kan geskied. ${ }^{3}$

Scholander se ontwerpe van konstante drukrespirometers oor baie jare ${ }^{8.9 .10 .11}$ het bewys dat sy respirometers baie prakties en betroubaar is indien dit deur 'n goeie instrumentmaker gebou kan word. Verder kan Scholanderrespirometers aangepas word vir verskillende groottes diere wat of in lug óf in 'n akwatiese medium respireer. Die konstante drukrespirometer wat vir vis ontwerp is, ${ }^{8}$ word reeds vir baie jare in hierdie laboratorium vir die meting van die suurstofopnamekoers by visse gebruik. Die respirometer (fig. 4) is egter verbeter ${ }^{14}$ ten opsigte van die dryfas wat die waterroerder laat draai. Dit is vervang met 'n magnetiese roerder wat deur 'n water- en lugdigte perspekswand $(w)$ werk. Hierdie verandering verseker dat lekkasies van die respirasiemedium, hetsy lug of water, uitgesluit is. Ook is die kaliumhidroksiedreservoir en die roterende waterroerder naby mekaar geplaas. Sodoende kan die apparaat ook gebruik word om die suurstofverbruik van terrestriële diere te meet (fig. 4). Hierdie plasing van die $\mathrm{KOH}$ naby die roerder het tot gevolg dat die lug (waarin $\mathrm{CO}_{2}$ voorkom) goed geroer word sodat die $\mathrm{CO}_{2}$ chemies met die KOH kan bind. Die rivierkrap Potamonautes warreni se suurstofverbruikskoers in water en in lug is suksesvol met hierdie respirometer gemeet. ${ }^{14}$ Hierdie tipe Scholanderrespirometers kan nadelig wees ten opsigte van die gebruikte meettyd as die respirasiekamer se volume byvoorbeeld 100 keer groter is as die volume van die respirerende dier. Dit beteken in die praktyk dat tydintervalle van 6 tot 12 uur nodig is vir opeenvolgende lesings, omdat die manometerrespons baie stadig is vir klein proefdiere in 'n groot respirasiekamer. Die ideaal is dat die respirasiekamervolume nie meer as vyf keer die volume van die respirerende dier moet wees nie. 'n Te groot respirasiekamer kan ook lei tot onnoukeurige aflees van die manometermeniskus nadat dit na die nulpuntposisie teruggebring is. ' $n$ Groot 


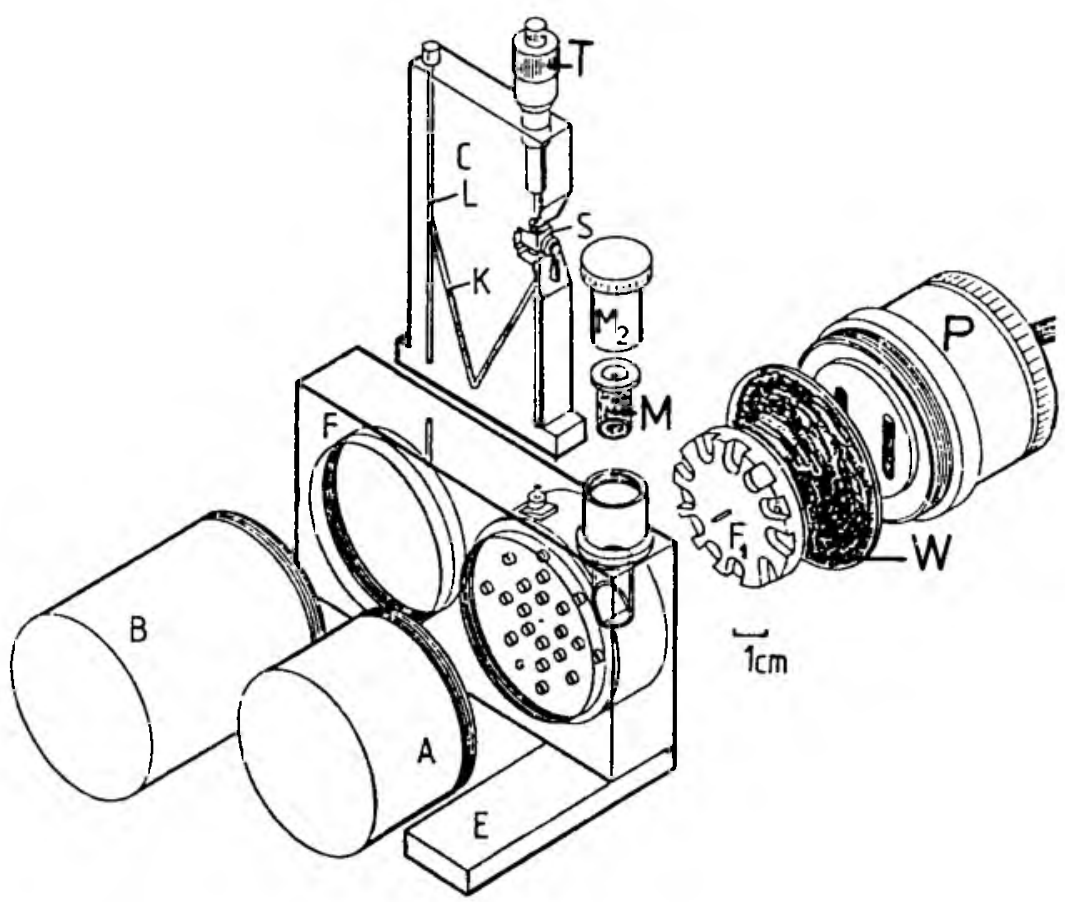

FIGUUR 4: 'n Scholanderrespirometer vir akwatiese diere. A, respirasiekamer. B, drukkompensasiekamer. F, perspeksblok waaraan die motor $(P)$ en manometer $(C)$ vasgeskroef word. $M_{2}$, perspeksprop wat $K O H$-houer binne respirasiekamer seël. $K$, manometer. $L$, verbindingsbuis. $T$, mikrometer. $E$, koper voetstuk. $F_{1}$, roerder.

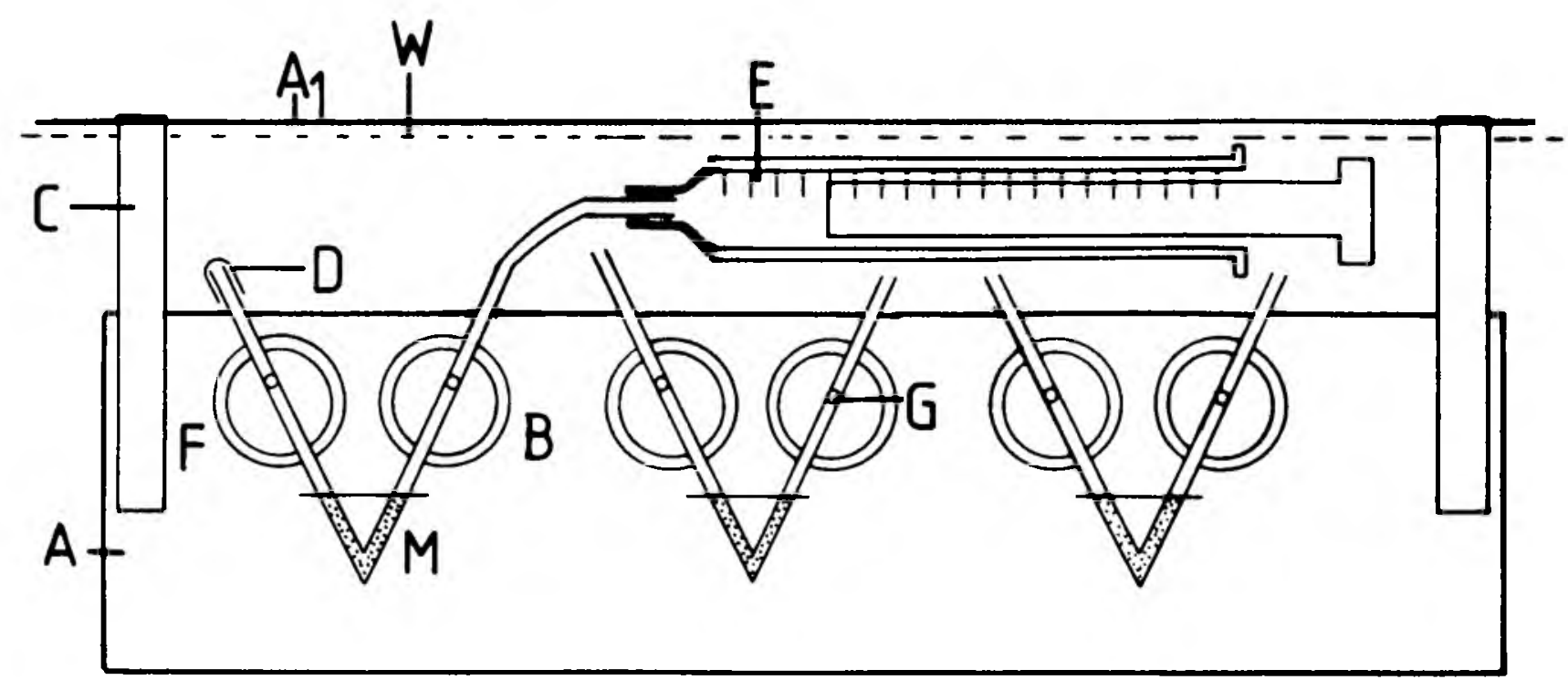

FIGUUR 5: 'n Scholanderrespirometer waarvan die kompensasiekamer en respirasiekamer direk in verbinding met die manometer is. ' $n$ Stel van drie respirometers is uit een perspeksblok (A) gemaak. $A_{l}$, borand van waterbad. A, perspeksblok. $B$, voorkant van respirasiekamer. $C$, metaaldraer vir perspeksblok. $D$, prop. $E$, spuit geyk in mikroliters. $F$, kompensasiekamer. $M$, manometer. $G$, gaatjie na respirasiekamer/kompensasiekamer.

respirasiekamer het tot gevolg dat 'n klein uitwyking op die manometer 'n relatief groot volume suurstofverbruik van die dier voorstel. Hierdie klein verandering in die manometerstand moet dan met 'n relatief groot volume suiwer suurstof in die spuit na die nulpunt teruggebring word. Hierdeur kan die swak reagerende manometerkolom nie altyd noukeurig op die nulpuntposisie geplaas word nie. 'n Oplossing hiervoor is om 'n klein respirasiekamer te gebruik en die manometerbuis met 'n baie klein deursnee te voorsien. Vir die doel is manometers (gemaak van glas) met 'n kapillêre deursnee van $0.5 \mathrm{~mm}$ baie doel- treffend. Krebs ${ }^{15}$ se watergebaseerde manometervloeistof met 'n soortlike digtheid van 1,033 by $20^{\circ} \mathrm{C}$ is geskik vir bykans alle manometriese respirometers.

'n Scholandertipe konstantedrukrespirometer, ${ }^{16}$ gemaak uit perspeks waarby die respirasie- en kompensasiekamer direk met die v-vormige manometer in verbinding is (fig. 5), word in hierdie laboratorium gebruik om die suurstofopnamekoers van die skerpioen Opisthophthalmus latimanus ( $3 \mathrm{~g}$ in massa) te meet. Vir die metings van hiedie terrestriële lugasemhalende dier was dit nie nodig om die respirometer te skud soos vir akwatiese diere wat in water 
asemhaal nie, omdat die snelheid van diffusie van suurstof in lug 10000 keer vinniger as in water is. Die volume van die respirasiekamers vir die $\mathrm{MO}_{2}$ metinge by skerpioene was $6 \mathrm{ml}$. Met die hulp van 'n $0.5 \mathrm{ml}$-gasdigte spuit (10 $\mu l$ per divisie) kon 'n noukeurigheidsgraad van onder 10 $\mu l$ per uur verkry word (ongepubliseerde resultate). Dit is gevind dat klein respirasiekamers en groot kompensasiekamers die sensitiwiteit van die metinge verhoog. Die meetprosedure is kortliks soos volg: 'n hoeveclheid van 'n 0.5 $\mathrm{ml} 12 \% \mathrm{KOH}$-oplossing word op $20 \mathrm{~cm}^{2}$ Whatman $\mathrm{nr}$. 1-filltreerpapier gedrup sodat dit die hele oppervlak van die papier bedek. Die filtreerpapier word silindries gevou en in 'n $5 \mathrm{ml}$-poliëtileenflessie met platiekdeksel, waarvan die wande en bodem geperforeer is, geplaas. Die flessic word in die respirasickamer geplaas, gevolg deur die skerpioen. Tydens die metinge word die respirometer onder water in 'n waterbad $\left(25^{\circ} \mathrm{C} \pm 0,5^{\circ} \mathrm{C}\right)$ gehou. $\mathrm{Na}$ in periode van 30 minute vir termo-barometriese ewewig word die manometeropening aan die kompensasickamer se kant gesluit. Die 0,5 ml-gasdigte spuite (wat met suiwer suurstof gevul is) word op dieselfde moment met die manometeropening aan die respirasiekamer se kant verbind. Die voordele van die Scholandertipe respirometers is dat dit maklik vervoer kan word en dat veldopstellings nie uitgesluit is nie. Hierdie respirometers is ook baie goedkoper as dit vergelyk word met polarografiese suurstofsensors. ${ }^{14}$ Nog 'n voordeel is dat konstante volumerespirometers so verklein kan word dat die suurstofopnamekoers van 'n enkele dier so klein soos $1 \mathrm{mg}$ in massa soos Daphmia ${ }^{16}$ of groter diere $\left(5-10 \mathrm{mg}\right.$ ) soos kleiner kewers of miere ${ }^{17.18}$ hiermee gemeet kan word (fig. 6). By hierdie miniatuurrespirometers geld dieselfde beginsel, naamlik dat die gasvolumes van veral die respirasiekamers so klein moontlik gehou moet word vir beter sensitiwiteit. Dus is die volume van die respirasiekamer 0,5 tot $1,0 \mathrm{ml}$ vir die meet van $1 \mathrm{mg}$ diere, met 'n noukeurigheid van $0,05 \mathrm{~mm}^{3}$ per uur: 3 to 3 tot $4 \mathrm{ml}$ vir diere met 'n massa van 1 tot $20 \mathrm{mg}$, met 'n nou- keurigheid van $1 \mathrm{~mm}^{3}$ per uur; ${ }^{17} 20$ tot $30 \mathrm{ml}$ vir diere van I tot $3 \mathrm{~g}$, met 'n noukeurigheid van $10 \mathrm{~mm}^{3}$ per uur; ${ }^{17} 100$ $\mathrm{ml}$ vir diere met 'n massa van 20 tot $30 \mathrm{~g}$ met 'n noukeurigheid van $20 \mathrm{~mm}^{3}$ per uur, ${ }^{18}$ en een liter vir diere van 100 $\mathrm{g}$ in massa, met 'n noukeurigheid van $100 \mathrm{~mm}^{3}$ per uur. ${ }^{14}$

\section{Nadele van manometriese respirometers}

Een van die grootste nadele van respirometers wat op die manometriese beginsel werk, is dat metings in kort intervalle gemaak moet word deur die manometer weer na die nulpuntposisic terug te bring. Dit verg langdurige persoonlike aandag en kraanmanipulasies met die hand.

On hierdie probleem op te los is elektrolitiese respirometers ontwikkel $\left.{ }^{1221}\right)$ sodat, sonder persoonlike toesig, die regte volumehoeveelheid suurstof elektrolities bygevoeg word. Hierdie byvoeging word elektronies geregistreer en sodoende kan die suurstofverbruikskoers bepaal word. Die meetprosedure is kortliks soos volg: die dier word in 'n verseëlde kamer geplaas en die gec̈kspireerde $\mathrm{CO}_{2}$ word chemies deur $4 \% \mathrm{KOH}$ op filtreerpapier geabsorbeer (fig. 7). Suurstof wat deur die respirerende organisme opgebruik word. veroorsaak dat die druk in die respirasiekamer en verseëlde ruinte daal. Dit het tot gevolg dat die versadigde kopersulfaatoplossing styg en met die platina-anode in die dik glaskapillêr in aanraking kom. 'n Stroom $(1,0 \mathrm{~mA})$ ontstaan vanaf 'n konstante stroombron, wat ook 'n digitale teller in werking stel. Met die gebruik van Faraday se Wet kan bereken word dat, in hierdie geval $(1,0 \mathrm{~mA}$ puls van 0,1 sekonde), $5,8039 \mathrm{nl}$ suurstof geproduseer word vir een puls by standaarddruk en -temperatuur. Die teoretiese gasvolume per puls $\left(\mathrm{V}_{1}\right)$ by 'n gegewe temperatuur kan dan bereken word as:

$$
V_{1}=5,8039 \times(273+t) / 273
$$

Die suurstof wat by die platina-anode vrykom, diffundeer opwaarts in die glaskapillêr se lumen tot by die respirasickamer, waar dit weer vir respirasie beskikbaar is. In die

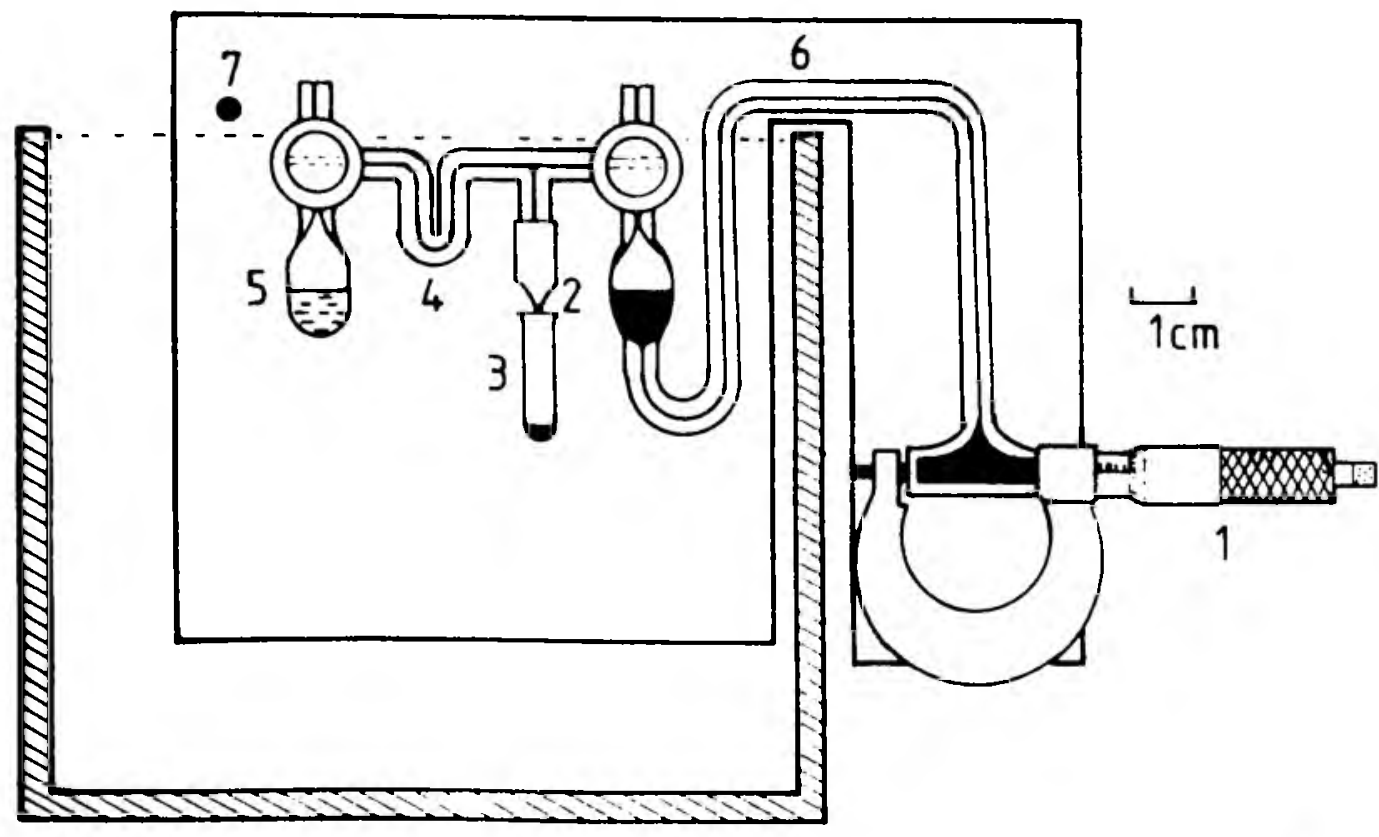

FIGUUR 6: 'n Konstante drukrespirometer vir klein insekte met 'n noukeurigheidsgraad van 0,33 $\mathrm{mm}^{2}$ per uur. I, mikrometer. 2, stoorruimte vir suurstof. 3, respirasiekamer. 4, manometer. 5, kompensasiekamer. 6, ruspunte van perspeksraam. 7, drapen van perspeksraum. Die lengte van die respirometer is $15 \mathrm{~cm}$. 


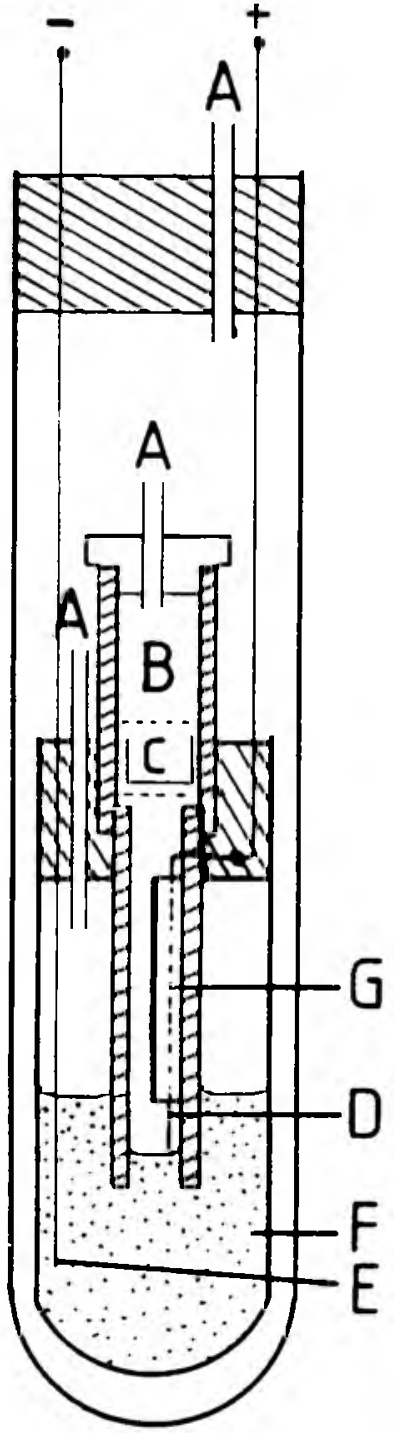

FIGUUR 7: Die elektrolitiesc respirometer vir klein terrestriële invertebrate. $A$, inlate vir gasdrukewewig. $B$, respirasiekamer. $C$, houertjie met $15 \% \mathrm{KOH}$-oplossing. D, platina-anode. E, koperkatode, $F$, versadigde kopersulfaatoplossing. $G$, glaskapillêre.

praktyk is hierdie elektrolitiese respirometer vir ten minste 8 dae lank gebruik vir sowel terrestriële as akwatiese diere van nie groter as $10 \mathrm{mg}$ in lewende massa nie. ${ }^{19}$ Een van die probleme wat kan ontstaan, is die vorming van osoon by elektrolitiese respirometers. Woodland ${ }^{20}$ stel egter voor dat osoon in respirometers gekataliseer word deur die gebruik van nikkel di-N-butielditiokarbamaat.

\section{Cartesiese duikers}

Die meting van die respirasie-aktiwiteit van klein terrestriële arthropode, soos Collembola en Acari wat kleiner as $1 \mathrm{mg}$ is, vereis ' $\mathrm{n}$ metode van meting wat ordes meer sensitief moet wees as konvensionele manometriese respirometrie. As die suurstofverbruik van eensellige alge, protosoë en enkele selle of ontwikkelende eiers van meersellige diere gemeet moet word, is bestaande manometriese metodes te onnoukeurig. Hiervoor is die Cartesiese duiker ontwikkel. ${ }^{2 \prime}$

'n Groot voordeel van Cartesiese duikerrespirometrie is dat dit betreklik goedkoop is om die duikertjie en ander onderdele te vervaardig. Die belangrikste is egter dat dit 'n noukeurigheidsgraad van minstens $10^{\circ} \mu \mathrm{l} \mathrm{O}_{2}$ per uur besit. Nadele van hierdie tipe mikrorespirometrie is dat sekere vaardighede eers bemeester moet word en ook dat dit tydrowend is om die metings te doen. Sedert die eerste beskrywing van die Cartesiese duiker het dit heelwat ontwikkelinge ondergaan en kan daar gevolglik 'n onderskeid tussen twee tipes gemaak word.

Oop duikers (fig. 8A)

Die oorspronklike vorm bestaan uit 'n Pyrex-glasbuisie waarvan die een kant oop is en aan die toe kant voorsien is van 'n soliede glasstafie wat as 'n soort "kielmassa" optree. In die middelste gedeelte, wat bolvormig is, word die diertjie geplaas. In die oop nekgedeelte, aan die onderkant van die nek, word KOH geplaas, gevolg deur 'n olieseël en dan 'n mondseël wat gewoonlik dieselfde tipe oplossing is as dié waarin die duikertjie gaan dryf. Oop- of standaardduikers word nie slegs as respirometers gebruik nie, maar ook vir sekere biochemiese prosesse waar gasse geproduseer of opgeneem word.

\section{Glaspropduikers (fig. 8B)}

Hierdie tipe duiker is baie geskik om die metabolisme van diere te bepaal. Hierdie tipe duikers is deur Zeuthen ${ }^{22}$ ontwikkel. Oor die algemeen is die konstruksie, hantering en voorbereiding van hierdie tipe duikers makliker as dié van die oop tipe. Dit kan vir sowel terrestriële as akwatiese diere gebruik word. Die noukeurigheidsgraad is omtrent $10^{-6} \mu l$ per uur.

\section{Nie-Cartesiese gradiëntduikers (fig. 8C)}

Dit het die vorm van 'n klein ampulla wat bo toe is. Die onderste deel het ' $n$ lang stert wat oop is. Hierdie glasduiker dryf met sy stert na onder in 'n $\mathrm{Na}_{2} \mathrm{SO}_{4}$-oplossing wat as 'n soortlike digtheidsgradiënt opgemaak is (1,00 aan die bokant tot 1,06 op die bodem van die lang fles). Die diertjie word aan die bodeel van die ampulla gehou met die hulp van poreuse polistireen. 'n Klein hoeveelheid $5 \%-\mathrm{NaOH}$ word in die kapillêre stertgedeelte opgesuig, wat dien om die $\mathrm{CO}_{2}$ wat respiratories afgegee word, chemies te bind. Gradiëntduikers, met 'n noukeurigheidsgraad van $0,75 \mathrm{nl}$ per uur, is deur Nexo et $\mathrm{al}^{23}$ vir akwatiese diere en deur Petersen ${ }^{24}$ vir terrestriële diere (Collembola) ontwikkel. Streng gesproke kan die gradiëntduiker nie as 'n egte Cartesiese duiker gegroepeer word nie. ${ }^{25}$

\section{Geslote duikers (fig. 8D)}

Hierdie tipe duiker werk in beginsel dieselfde as die glaspropduiker. Wanneer die suurstof in die lugruimte binne die perspeksonderstuk (4) deur die dier verbruik word en koolstofdioksied chemies met die $\mathrm{NaOH}$-oplossing bind, verklein die gasruimte deurdat die $\mathrm{NaOH}$-oplossing via die gaatjie in die proppie die plek daarvan inneem. Die duikertjie word swaarder as die omringende $\mathrm{NaOH}$-oplossing en die duikertjie sink. Met behulp van die manometer word die ewewigdruk van die duiker bepaal en met verdere berekeninge kan die $\mathrm{MO}_{2}$ van die diertjie vasgestel word. Die voordeel van hierdie tipe duikertjie is hoofsaaklik dat dit uit perspeks vervaardig is en dus nie maklik kan breek nie.

\section{Die werksbeginsel van 'n Cartesiese duiker}

'n Cartesiese duiker is 'n konstantevolume, veranderdedruk- manometriese gasmeter en word dit gegroepeer onder 

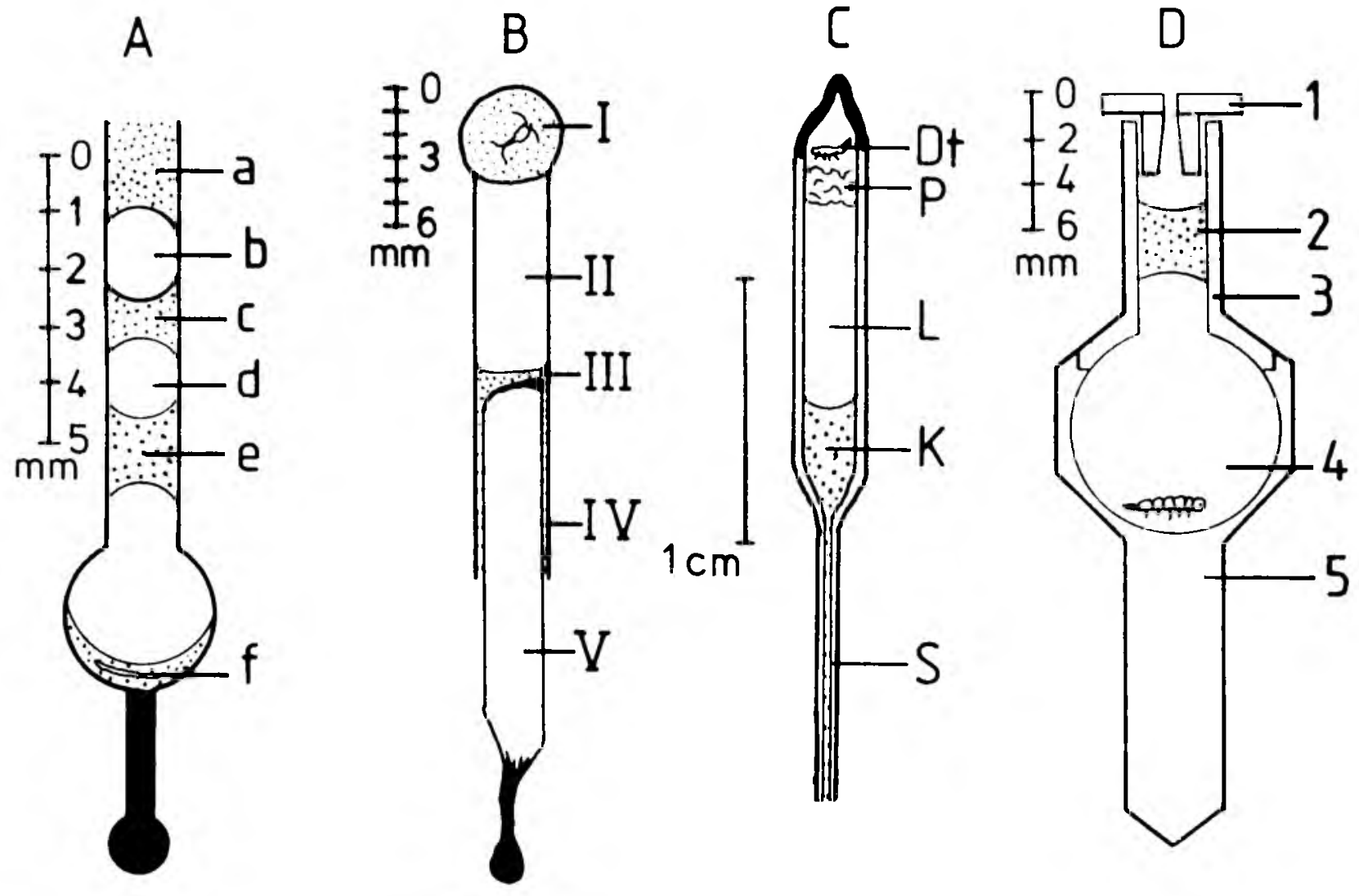

FIGUUR 8: A, B, C, D, Vier tipes duikers. A: Oopduiker. a, flotasiemedium. $b$, lug. $c$, olieseël. d, lugruimte. e, NaOHoplossing. $f$, waterlagie met akwatiese diertjie. B: Glaspropduiker. I, watervolume met akwatiese dier. II, lugruimte. III, $0,1 \mathrm{~mol} \mathrm{NaOH}$-oplossing. IV, duikerliggaam. V, glasprop met massa. C: Gradiëntduiker. Dt, terrestriële dier. P, polistireen. L, lugruimte. $\mathrm{K}, \mathrm{NaOH}$-opolossing. S, stertstuk. D: Geslote duiker gemaak van perspeks. l, proppie met gaatjie. 2, 0,I mol $\mathrm{NaOH-oplossing.} \mathrm{3,} \mathrm{perspeksbostuk.} \mathrm{4,} \mathrm{perspeksonderstuk.} \mathrm{5,} \mathrm{perspeksmassa.}$

die klassieke Warburgrespirometers en nie onder die Scholandertipe respirometers nie. Laasgenoemde werk volgens die beginsel van konstantedrukveranderde volume. Die glaspropduiker bestaan gewoonlik uit 'n glashouer wat 'n gasvolume insluit (fig. 8B). Die gasvolume is direk in verbinding met die omringende flotasiemedium wat uit $0,1 \mathrm{~mol}$ $1^{1} \mathrm{KOH}$ bestaan. As die suurstof in die gasvolume van die duiker verbruik word (die $\mathrm{CO}_{2}$ word deur die $\mathrm{KOH}$ geabsorbeer), daal die druk in die duiker. Hierdie daling word opgehef en in ewewig gebring deurdat ' $n$ bietjie $\mathrm{KOH}$ oplossing in die duiker inbeweeg. Die gevolg hiervan is dat die duiker nie meer soveel flotasiemedium verplaas nie en die duiker tot by die bodem van die flotasiefles sink. Om die volume van die duiker weer na die oorspronklike terug te bring word die druk in die flotasiefles met die hulp van die manometer verlaag. Hierdie verskil in die druk (begindruk minus einddruk, $\triangle \mathrm{P}$ ) word gebruik om die suurstofverbruik per indiwidu per uur $\left(\mathrm{VO}_{2}\right)$ te bereken. Die volgende vergelyking word hiervoor gebruik: ${ }^{26}$

$$
\dot{\mathrm{Vo}}_{2}=\frac{\mathrm{Vg} \times \mathrm{P}}{\mathrm{P}_{\mathrm{o}}} \times \frac{273}{\mathrm{~T}}
$$

waar:

$\mathrm{VO}_{2}=$ suurstofverbruikskoers per individu per uur;
$\mathrm{Vg}=$ gasvolume $(\mu \mathrm{l})$ in duikers (=duikerkonstante, $\mathrm{yk}$ volume);

$\triangle \mathrm{P}=$ verskil in ewewigsdruk per uur in mm Brodie;

$\mathrm{P}_{\mathrm{o}} \quad=$ normale druk $(10000 \mathrm{~mm}$ Brodie $) ;$

$\mathrm{T}=$ absolute temperatuur $(\mathrm{K})$

Duikerkonstante (ykvolume): $\mathrm{Vg}$

Hierdie volume $(\mathrm{Vg})$ word vir die glaspropduiker met behulp van ' $n$ tienmikroliter-Hamiltonspuit afgemeet. Ongeveer 1 tot $2 \mu \mathrm{l}$ word presies afgemeet en in die kopgedeelte van die duikertjie geplaas. As die duikertjie van perspeks gemaak is en die flotasiemedium is $0,1 \mathrm{~mol} / 1 \mathrm{NaOH}$ (fig. 8D), word die gasvolume by ewewigsdruk vir elke afsonderlike duiker soos volg bereken:

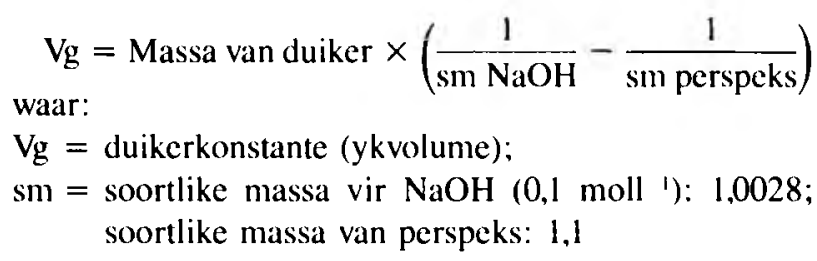

Die duikerkonstante van die perspeksduikers wat in hierdie laboratorium gebruik word, is gemiddeld $94,1 \mu$, maar deur weging moet die duikerkonstante van elke duiker vasgestel word. 


\section{B. ELEKTROCHEMIESE METODES}

Respirometers wat ontwerp is om die suurstofkonsentrasie in water deur middel van elektrochemiese suurstofsensors te meet het, sedert $\mathrm{Clark}^{27}$ se uitvinding van die membraanbedekte polarografiese elektrode, groot opgang gemaak. Ongelukkig kon suurstofkonsentrasies met hierdie metode nie in lug vir terrestriële diere gemeet word nie, maar slegs in water as respirasiemedium. Die onlangse ontwikkeling van die sirkoniumsuurstofsensor het navorsers egter in staat gestel om ook suurstofverbruik van lugasemhalers te meet (kyk later). Die polarografiese suurstofsensor (PSS) het 'n noukeurigheidsgraad van $3 \mathrm{nmol} 1^{1} \mathrm{O}_{2}$ per uur, terwyl 'n Cartesiese duiker 'n sensitiwiteit van 0,05 mmol $1^{-1} \mathrm{O}_{2}$ per uur het. Die suurstofverbruik van die katode ( $20 \mu \mathrm{m}$ in deursnee) vir die PSS is gewoonlik minder as $1 \mathrm{nmol} 1^{-1} \mathrm{O}_{2}$ per uur. ${ }^{28}$

\section{Die Clarkpolarografiese suurstofsensor (PSS)}

Die werksbeginsel van die polarografiese suurstofsensor van Clark is soos volg (fig. 9): 'n spanning word toegepas sodat 'n platinakatode in 'n negatiewe potensiaal ten opsigte van die elektrolietoplossing is. Die ander elektrode, naamlik die anode in die elektriese sel, is nie polariserend nie en bestaan uit ' $n$ silwerbandjie. Die toegepaste spanning is te laag om elektrolise in die sel te veroorsaak, met die gevolg dat die platinakatode gepolariseer word. Waterstof word gevolglik op sy blootgestelde oppervlak gevorm. Suurstof diffundeer deur die membraan en verbind met die

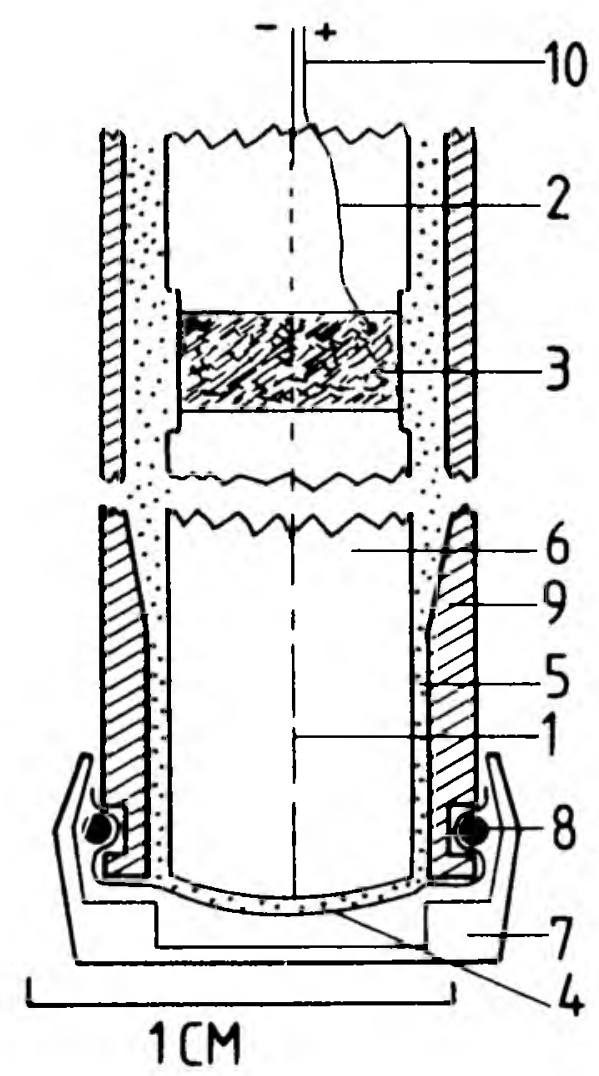

FIGUUR 9: Die Clarkpolarografiese suurstofsensor. 1, platinakatode. 2, silweranode geheg op silwer-silwerchloriedbandjie. 3, silwer-silwer-chloriedbandjie. 4, teflonmembraan. 5, elektroliet. 6, glasliggaam. 7, rubberkous. 8, O-ring. 9, plastiekhuls. I0, koaksiaalkabel. waterstof om water of waterstofperoksied te vorm. Hierdie depolarisasie verander die hoeveelheid stroomvloei in die elektrode. Die hoeveelheid stroomvloei wat verander, hang direk af van die konsentrasie en die snelheid van suurstofbeweging deur die membraan. As die konsentrasie van suurstof aan die binnekant van die membraan laag bly, is die verandering van die elektrodestroom direk eweredig aan die uitwendige suurstofkonsentrasie oor 'n baie wye konsentrasiegebied. Die belangrikste faktore wat die suurstofbeweging deur die membraan beinvloed, is temperatuur, dikte van die membraan, elektrolietouderdom en roering van die water aan die buitekant van die membraan. Om hierdie redes word PSS altyd geyk vir die bepaalde eksperiment waarvoor dit gebruik word. Die elektrochemiese gebeure in die omgewing van die katode en anode word soos volg voorgestel: ${ }^{29}$

$$
\begin{aligned}
& \text { Platina-elektrode (katode): } \\
& 2 \mathrm{H}^{+}+2_{\mathrm{c}}^{-}+\mathrm{O}_{2} \rightarrow \mathrm{H}_{2} \mathrm{O}_{2} \\
& \left(\mathrm{H}_{2} \mathrm{O}_{2}\right)+2 \mathrm{H}^{+}+2 \mathrm{e}^{-} \rightarrow 2 \mathrm{H}_{2} \mathrm{O}
\end{aligned}
$$

Silwerelektrode (anode):

$4 \mathrm{Ag}+4 \mathrm{Cl} \rightarrow 4 \mathrm{AgCl}+4^{-}$

(Die elektrone wat by die anode ontstaan, word deur die platinakatode gebruik om suurstof te reduseer.)

Hierdie tipe PSS word volgens elektrochemici ${ }^{29}$ geklassifiseer as 'n voltametriese PSS, omdat 'n spanning van 0,6 volt met behulp van 'n bron geskep moet word.

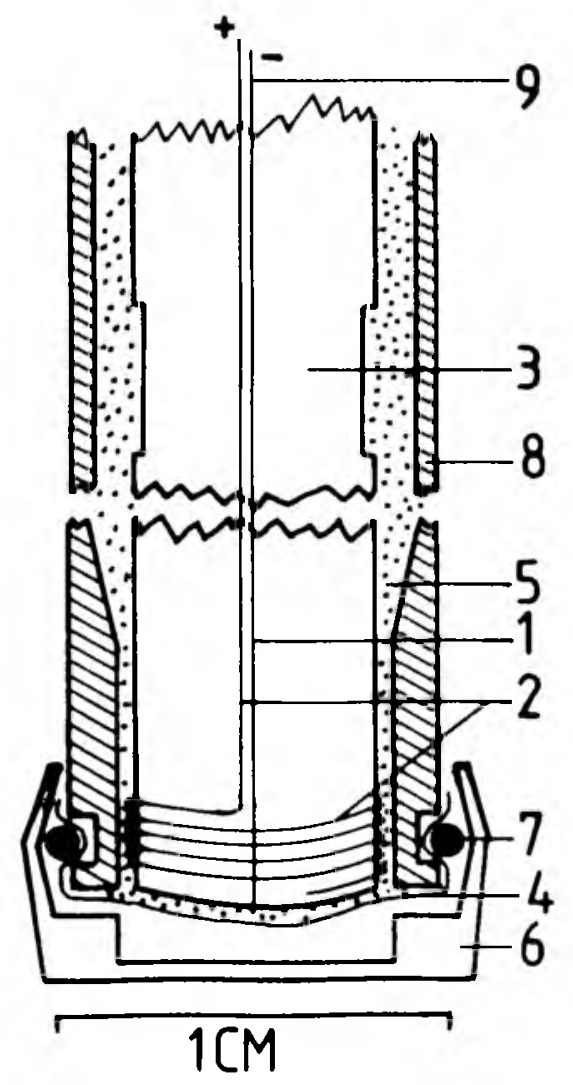

FIGUUR 10: Die silwer-lood-galvaniese polarografiese suurstofsensor. 1, silwerkatode. 2, loodanode. 3, epoksieharsliggaam. 4, teflonmembraan, 5, elektroliet ( $\left.\mathrm{NaHCO}_{3}\right)$. 6, rubberkous. 7, O-ring. 8, plastiekhuls. 9, koaksiaalkabel. 


\section{Die silwer-lood-galvaniese polarografiese suurstofsen- sor (PSS)}

Hierdie tipe elektrode is deur $\mathrm{Hahn}^{30}$ ontwikkel vir bloedgasanalises en deur Mackereth ${ }^{31}$ aangepas vir die langdurige registrasie van suurstof in vloeistowwe of gasse (fig. 10). Die elektrochemiese prosesse is soos volg: vir die werking van hierdie elektrode is dit nie nodig om 'n uitwendige spanningsbron te verskaf nie. Daar is reeds 'n potensiaalverskil tussen die silwerkatode en die spiraalgedraaide loodanode.

Silwerkatode:

$$
\frac{1}{2} \mathrm{O}_{2}+\mathrm{H}_{2} \mathrm{O}+2 \mathrm{e}-\rightarrow 2 \mathrm{OH}
$$

Loodanode:

$$
\begin{aligned}
& \mathrm{Pb} \rightarrow \mathrm{Pb}^{2+}+2 \mathrm{e} \\
& \mathrm{Pb}^{2+}+2 \mathrm{OH} \rightarrow \mathrm{Pb}(\mathrm{OH})_{2}
\end{aligned}
$$

Gesamentlik: $\frac{1}{2} \mathrm{O}_{2}+\mathrm{Pb}+\mathrm{H}_{2} \mathrm{O} \rightarrow \mathrm{Pb}\left(\mathrm{OH}_{2}\right)$.

Die galvaniese PSS het voordele bo die voltametriese PSS, omdat dit (i) ten minste 3 keer vinniger reageer as die voltametriese elektrode ${ }^{30}$ en (ii) vir langtermynmetings van 'n paar weke beter stabiliteit gee. ${ }^{31}$ Dat die galvaniese elektrode enigsins die voltametriese elektrode in bloedgasen langtermyn biologiese meting sal vervang, is te betwyfel. Die vernaamste rede hiervoor is dat vervaardigers reeds 'n voorsprong het in die vervaardigingsproses van die Clarktipe polarografiese elektrode. Ekonomiese redes sal dus swaarder opweeg teenoor die goeie responstyd en liniêre eienskappe van die galvaniese sel. Met behulp van die PSS is 'n groot verskeidenheid respirometers deur navorsers ontwikkel om in hulle bepaalde behoeftes te voorsien.

\section{Geslote stelselrespirometers}

Hierdie tipe respirometers is maklik om te ontwerp en word gebruik om korttermynmetings te maak. In beginsel word 'n bepaalde volume water met lug versadig gemaak. Die aanvangs- $\mathrm{PO}_{2}$ word gemeet kort nadat die volume water lugdig van die atmosfeer afgeseël is. $\mathrm{Na}$ die verloop van 'n bepaalde tyd, of tot die $\mathrm{PO}_{2}$ gedaal het tot ' $n$ waarde wat tot $50 \%$ minder as die aanvangswaarde is, word die metinge gedoen en die volume water waarin die dier is, weer versadig gemaak met lug. Die verskil in die aanvangs$\mathrm{PO}_{2}$ en finale $\mathrm{PO}_{2}$ gee $\triangle \mathrm{PO}_{2}$. Hierdie waarde word gebruik om die suurstofverbruikskoers vas te stel. Belangrike vereistes van die geslote stelsel is dat (i) die water goed geroer moet word; (ii) daar geen lugborrels in die respirerende watermedium vasgevang word nie; (iii) die verhouding van volume respirerende water en die suurstofverbruikskoers van die dier nie te hoog is nie; (iv) die $\mathrm{PO}_{2}$ van die respirasiemedium nie laer daal as wat die kritiese suurstofspanning, $P_{0}$, van die dier is nie. ${ }^{32}$ By hierdie spanning word die respirerende dier se suurstofverbruik beïnvloed deur die hipoksiese toestande van sy omgewing.

Alhoewel die nadele van geslote stelsels wel bekend is, ${ }^{33}$ meen Oertzen ${ }^{34}$ dat by $80 \%$ van alle respirometriese metings van akwatiese diere geslote respirometriestelsels gebruik word. 'n Belangrike aspek van geslote stelselrepirometrie is dat die watervolume goed geroer moet word. Dit het die gevolg dat die waterlagie teen die PSS gedurig vervang word sodat 'n maksimale suurstofgradiënt in stand gehou kan word. Behalwe vir die magnetiese roerder wat in baic gevalle gebruik is om die magnectvolger in die repirasiehouer te laat draai, is ook suksesvol gebruik gemaak van 'n wateraangedrewe turbine wat die magneetvolger laat draai. ${ }^{35.36}$ Die wateraangedrewe turbine wat die magneetvolger laat draai, kan op enige plek in die respirasiekamer ingebou word. Dit laat nie slegs ruimte om die respirasiekamer se posisie en vorm drasties te verander nie, ${ }^{35}$ maar ondervind ook geen probleme om die temperatuur van die respirasiewater te beïnvloed nie. Dit is in teenstelling met 'n ingeboude elektriese aangedrewe magneetvolger. Die volume van die respirasiekamer by geslotestelselrespirometrie kan wissel van 'n paar $\left.\mu\right|^{n}$ tot soveel as $950 \mathrm{ml}^{36}$ met 'n noukeurigheidsgraad van minder as $5 \%$.

\section{$\dot{\mathrm{MO}}$-berekeninge vir geslote stelselrespirometrie}

Hier volg 'n voorbeeld hoe om $\mathrm{MO}_{2}$ met die varswaterkrap as proefdier te bepaal. Om die $\mathrm{MO}_{2}$ te bereken moet die aanvanklike verandering in die $\mathrm{PO}_{2}$-waarde, $\triangle \mathrm{PO}_{2}$, eers vasgestel word. Hiervoor is die volgende gegewens nodig:

1. Netto volume van respirometerkamer $=905 \mathrm{ml}$.

(Die volume van die respirerende dier $=45 \mathrm{ml}$.)

2. Die oplosbaarheidskoëffisiënt, $\alpha$, van I liter varswater by $760 \mathrm{mmHg}$ lugdruk en $25^{\circ} \mathrm{C}$ moet bekend wees $\left(5,7878 \mathrm{ml} \mathrm{1}^{-1} .\right)^{38}$

3. Barometriese druk (Potchefstroom) $=655 \mathrm{mmHg}$.

4. Dampdruk van water by $25^{\circ} \mathrm{C}=23,8 \mathrm{mmHg}$.

5. Aanvangswaarde van $\mathrm{PO}_{2}$ in respirometer $(655-23,8$ $\times 20,9 \%)=132,1 \mathrm{mmHg}$.

6. Eindwaarde van $\mathrm{PO}_{2}$ (na 20 minute) in respirometer $=$ $80,0 \mathrm{mmHg}$.

7. Berekening en metinge van $\mathrm{MO}_{2}$ per kg diermassa per minuut:

$$
\begin{aligned}
& \dot{\mathrm{MO}}_{2}\left(\mathrm{mmoll}^{-1} \mathrm{O}_{2} \mathrm{~kg}^{-1} \min ^{-1}\right)= \\
& \frac{905^{\mathrm{al}}}{1000} \times \frac{655^{\mathrm{h}}}{760} \times \frac{5,7878^{\mathrm{c}}}{1} \times \frac{52,1^{\mathrm{d}}}{132,1^{\mathrm{c}}} \times \frac{1000^{\mathrm{f}}}{46,8^{\mathrm{g}}} \times \frac{1^{\mathrm{h}}}{22} \times \frac{1^{\mathrm{l}}}{20}
\end{aligned}
$$

waar:

$\mathrm{a}=$ netto volume van respirasiekamer $(950 \mathrm{ml}-45 \mathrm{ml}$; (= volume van die krap): $905 \mathrm{ml}$ );

$\mathrm{b}=$ barometerdruk in Potchefstroom: $655 \mathrm{mmHg}$;

$c=\alpha$, oplosbaarheidskoëffisiënt van varswater by 760 $\mathrm{mmHg}$ en $25^{\circ} \mathrm{C}$; 38

$\mathrm{d}=\triangle \mathrm{PO}_{2}: 52,1 \mathrm{mmHg}\left(\mathrm{PO}_{2}\right.$ is $132 \mathrm{mmHg}$ van water by aanvangstyd van respirasie $-\mathrm{PO}_{2}$ is $80 \mathrm{mmHg}$ na 20 minute respirasie);

$\mathrm{e}=\mathrm{PO}_{2}$ van water in Potchefstroom in $\mathrm{mmHg}$;

$f=$ suurstofverbruikskoers uitgedruk per kg krap;

$\mathrm{g}=$ massa van krap in $\mathrm{g}$;

$\mathrm{h}=$ gaskonstante per mmol $\mathrm{O}_{2}$ is $22,4 \mathrm{ml}$;

I = tyd verwerk na per minuut.

Hierdie waardes word dan verwerk na standaardtemperatuur $\left(0^{\circ} \mathrm{C}\right)$, druk $(760 \mathrm{mmHg})$ en droë lug (STDD. $)^{3}$

\section{Langtermyndeurvloei- of -oopstelselrespirometrie}

Die vernaamste voordele van hierdie stelsel is dat (i) ekskretoriese produkte $\left(\mathrm{NH}_{3}, \mathrm{CO}_{2}\right.$, laktaat, feses) wat dic suurstofverbruik van akwatiese diere beïnvloed, gedurig tydens hierdie tipe meting verwyder word; (ii) sirkadiese ritmes wat via die suurstofverbruikskoers weerspieël word, 


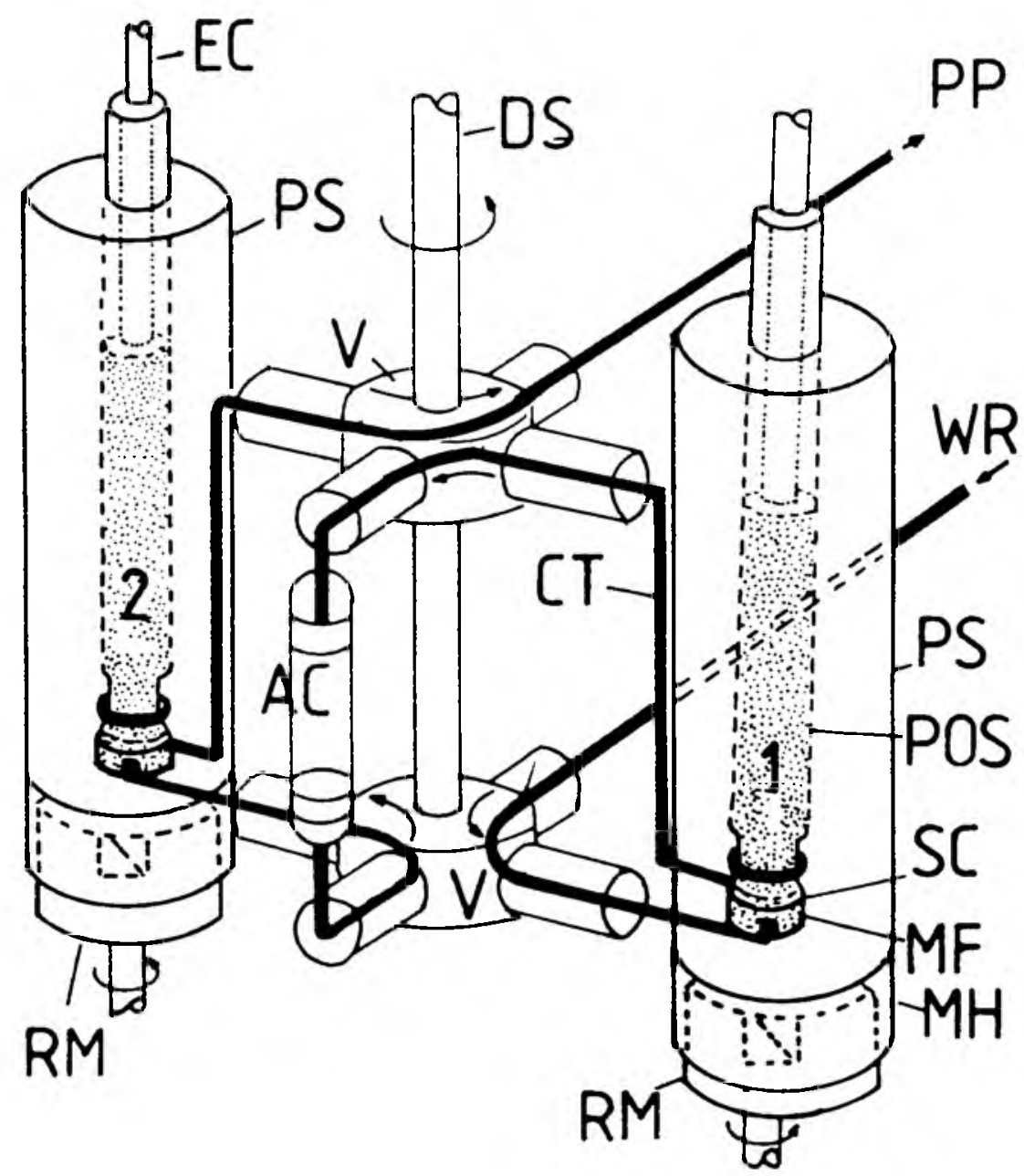

FIGUUR II: Die dubbelvloeirespirometer. Water vanaf 'n reservoir $(W R)$ word deur PSS(l) gestuur om die elektrode te yk. $P S S(2)$ is in bedryf en meet die $\mathrm{MO}_{2}$ van die diertjie in respirasiekamer $(A C)$. Die boonste 4-rigting $(V)$ en onderste 4-rigting (V) kleppe sorg dat die water alternerend na PSS(l) en PSS(2) gelei word. DS, dryfas vir kleppe. PS, mantel om elektrode. $P O S$, polarografiese suurstofsensor (PSS). Sc, roerderkamer. RM, draaiende magneet. CT, kapillêre buisie. $M H$, magneethuls. $M F$, magneetroerder.

ook gemeet kan word; (iii) geleidelike verandering in die suurstofverbruikskoers opgespoor en (iv) standaardmetabolisme bepaal kan word.

'n Groot nadeel van langtermyn-deurvloeirespirometrie is dat die platinakatode van die voltametriese PSS wat 20 $\mu \mathrm{m}$ dik is, en net by die glasoppervlak uitsteek, maklik met tyd bedek kan raak. Dit gebeur deur afsetting in die water en die vorming van bakteriële stowwe. In teenstelling hiermee is die galvaniese PPS minder onderhewig aan die bedekking van die katode tydens langdurige eksperimente. ${ }^{31}$

In beginsel word die verskil in die $\mathrm{PO}_{2}$-waardes tussen die ingangswater $\mathrm{PO}_{2}$ (i) en uitgangswater $\mathrm{PO}_{2}$ (ii) met PSS bepaal. Tesame met die vloeisnelheid van die water deur die dierekamer en die oplosbaarheidskoëffisiënt kan die suurstofverbruik, $\mathrm{Mo}_{2}\left(\mathrm{mmol}^{-1} \mathrm{O}_{2} 1^{-1} \mathrm{~kg}^{-1} \min ^{-1}\right)$, bepaal word:

1. Die oplosbaarheidskoëffisiënt, $\alpha$, van $1 \ell$ water by 760 $\mathrm{mmHg}$ en $25^{\circ} \mathrm{C}$ is $5,7878 \mathrm{ml} . .^{38}$

2. Die hoeveelheid $\mathrm{O}_{2}$ opgelos in $1 \mathrm{\ell}$ water in Potchefstroom by $25^{\circ} \mathrm{C}$ :

$=\frac{655}{760} \times 5,7878$

$=4,9881 \mathrm{ml} \mathrm{l}^{-1}$ by $132,1 \mathrm{mmHg}[655 \mathrm{mmHg}-23,8$ $\left.\mathrm{mmHg} \times 20,94 \% \mathrm{O}_{2}=132,1 \mathrm{mmHg}\right]$.
3. Die $\mathrm{PO}_{2}(1)$ is $132,1 \mathrm{mmHg}$ en $\mathrm{PO}_{2}(2)$ is $80 \mathrm{mmHg}$ vir 'n watervloeitempo deur die respirasiekamer van 150 $\mathrm{ml} \min ^{-1}$.

4. Die massa van die akwatiese dier is $59,9 \mathrm{~g}$. Die gaskonstante, $\mathrm{R}$, is $22,4 \mathrm{ml}$.

$$
\begin{aligned}
& =\frac{52,1}{132,1} \times \frac{4,9881}{1} \times \frac{150}{1} \times \frac{1000}{59,9} \times \frac{1}{22,4} \\
& \mathrm{MO}_{2}=255,1 \mathrm{mmol} \mathrm{l}^{-1} \mathrm{O}_{2} \mathrm{~kg}^{-1} \mathrm{~min}^{-1} .
\end{aligned}
$$

Hierdie waarde word dan verwerk na standaardtemperatuur $\left({ }^{\circ} \mathrm{C}\right)$, druk $(760 \mathrm{mmHg})$ en droë lug (STDD) ${ }^{3}$

Die meeste oopstelsels maak van 'n enkele Clarkelektrode gebruik. Deur middel van elektroniese skakelaars ${ }^{45}$ word die water alternerend vanaf verskeie respirometers aan die enkele Clarkelektrode blootgestel. ${ }^{34.40} \mathrm{Die} \mathrm{PO}_{2}$ van die inlaatwater word apart gemonitor nadat die respirasiemedium met lugsuurstof $100 \%$ versadig gemaak is. Hierdie lesing stel dan $\mathrm{PO}_{2}$ (1) voor, terwyl $\mathrm{PO}_{2}(2)$ afgelees word nadat die inlaatwater die respirasiekamer verlaat het. Die dubbelvloeirespirometer" bestaan uit twee Clarkelektrodes, waarvan die een elektrode die $\mathrm{PO}_{2}$ van die inkomende water meet terwyl die ander elektrode die $\mathrm{PO}_{2}$ van die uitgaande water meet. ${ }^{+041}$ Dit is noodsaaklik dat 


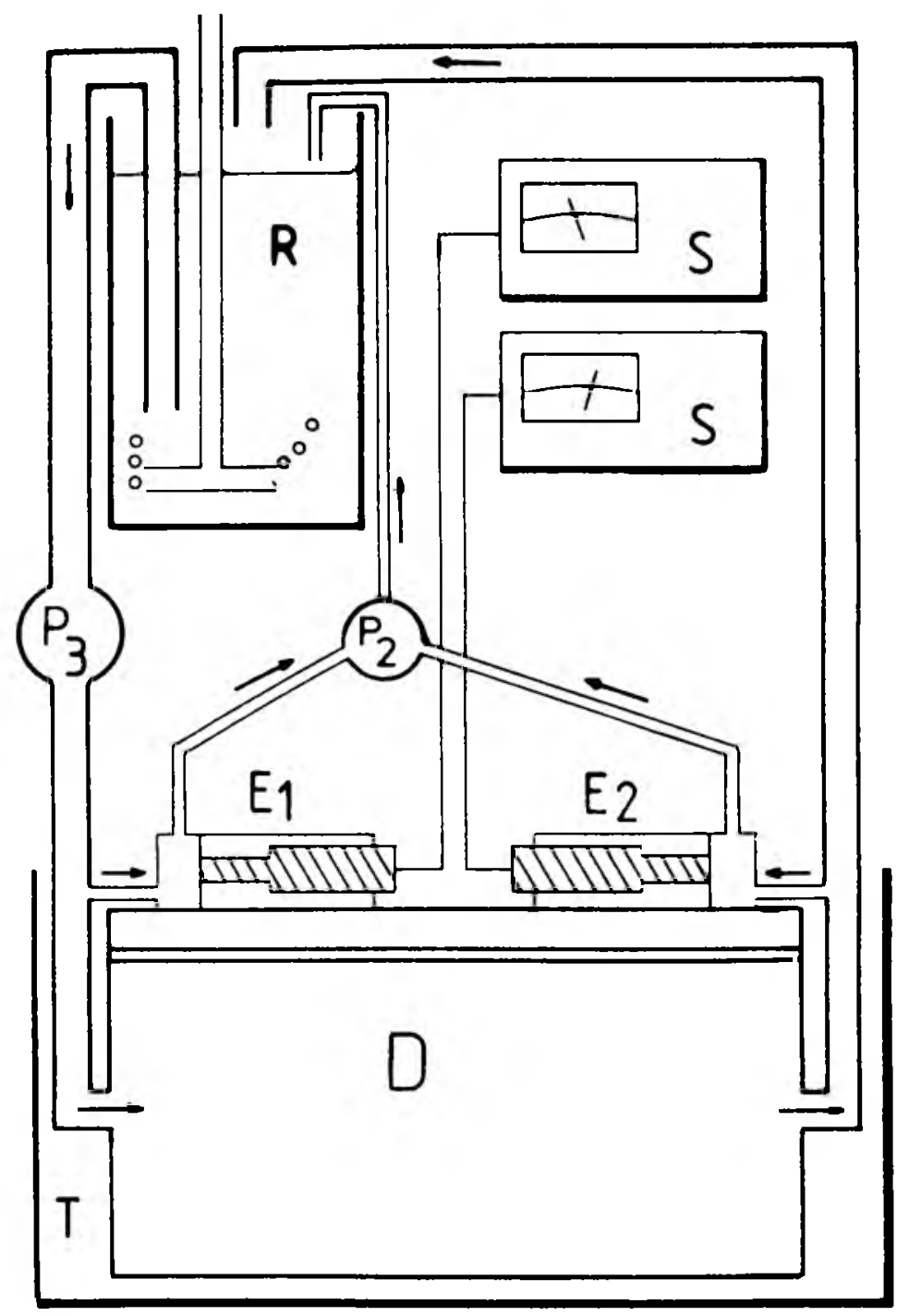

FIGUUR 12: 'n Diagrammatiese voorstelling van 'n dubbelvloeirespirometer waarby twee Clarkelektrodes (PSS) gebruik word. $D$, respirasiekamer. $E_{1}$ en $E_{2}$ twee termostatiese beheerde Clarkelektrodes. $P_{2}$, mikroperistalspomp. $R$, reservoir. $T$, waterbad. $S$, suurstofineters wat elk 'n Clarkelektrode bedien. $P_{3}$, pomp.

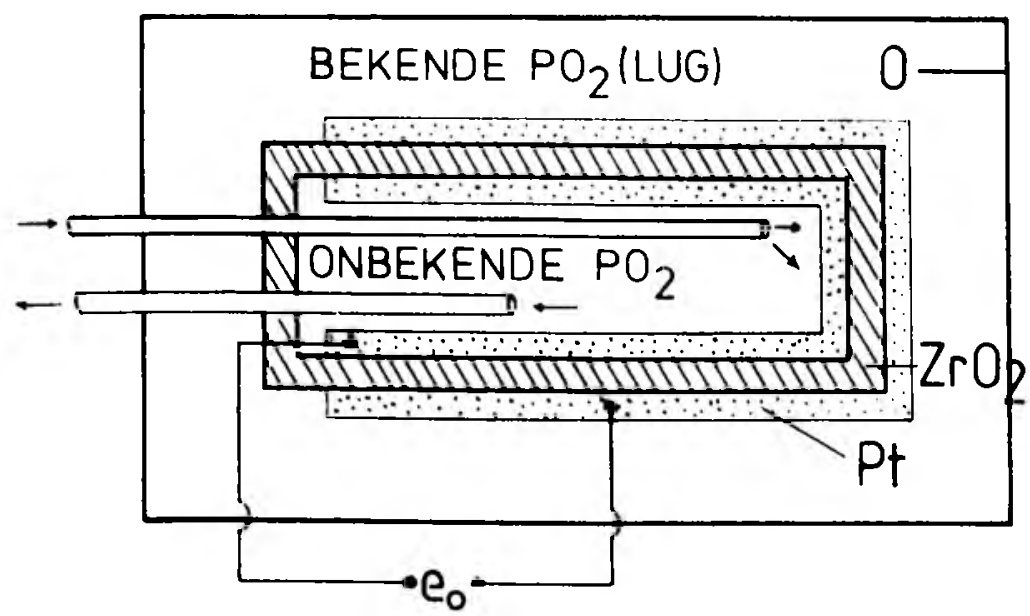

FIGUUR 13: Die sirkoniumsuurstofsensor. O, oond wat die platinabedekte sirkoniumdioksiedsilinder tot $750^{\circ} \mathrm{C}$ verhit. Pt. platinalaag. $\mathrm{ZrO}_{2}$, sirkoniumdioksiedsilinder. 
'n baie noukeurige mikroperistalspomp (P2) die water, as respirasiemedium, na die twee elektrodes pomp (fig. 12). Hoewel die gebruik van perspeks by die maak van die respirasiekamer ontmoedig word, ${ }^{41}$ is egter gevind ${ }^{42}$ dat 2 $\mathrm{mm}$ dik wande vir hierdie houers voldoende is om die permeabiliteit van suurstof deur die perspekswand te bekamp. Vir geslote stelsels met baie klein respirasiekamers wat die respirasiewater vir lang periodes stagnant moet hou, kan die perspekswand, suurstof deurlaat. As die suurstofverbruikskoers vir lugasemhalende diere by deurvloeistelsels gemeet moet word, word suurstof met 'n paramagnetiese sensor, gaschromatograaf of deur 'n massaspektrometer ${ }^{43}$ gemeet.

\section{Deurvloeistelsels vir lugasemhalende invertebrate}

Onlangs ${ }^{5}$ is meetapparatuur beskikbaar gestel om die suurstofverbruikskoers te meet deur gebruik te maak van die elektrolitiese eienskappe van sirkoniumdioksied $\left(\mathrm{ZrO}_{2}\right)$ by hoë temperature. Die sirkoniumsuurstofsensor is kommersieel bekombaar as 'n suurstofanaliseerder (Ametek Thermox, Instruments Division USA) vir die respirometrie van lugasemhalende diere van groter as 10 g. Basies bestaan die sensor uit 'n silinder wat aan die een kant gesluit is en gemaak is van sirkoniumdioksied wat gestabiliseer word deur kalsiumoksied by te voeg (fig. 13). Dun gasdeurlatende lae van platina, wat ook dien as elektrodes word op die binne- en buitekant van die silinder neergelê. Die silinder is gasdig sodat die meng van gasse aan die binne- en buitekant verhoed word.

Aan die oop kant van die silinder word ' $n$ inlaat- en uitlaatbuis voorsien om die toetsgas in die silinder te laat instroom. Die buite-elektrode is blootgestel aan die omgewingsgas, wat lug kan wees. Vir optimale funksionering moet die sensor verwarm word tot 'n temperatuur van tussen 360 en $800^{\circ} \mathrm{C}$. Vir die Ametek (S-3A-suurstofanaliseerder) word die $\mathrm{ZrO}_{2}$ by $750^{\circ} \mathrm{C}$ geleidend vir oksiedione en funksioneer dan as 'n elektroliet. Die reaksie: $\mathrm{O}_{2}$ $+4 \mathrm{e}^{-} \rightarrow 20^{2-}$ word by hierdie temperature volledig omkeerbaar en die sensor word 'n tipiese potensiometriese instrument. Die spanning wat geproduseer word, kan met die Nernstvergelyking bepaal word. Hierdie spanning is direk eweredig aan die verskil in suurstofkonsentrasie aan weerskante van die $\mathrm{ZrO}_{2}$-silinder.

\section{SIOTOPMERKING}

Die verskillende metodes om die suurstofverbruikskoers by akwatiese diere te meet het egter een nadeel gemeen. Dit is dat ' $n$ deel van die suurstof, opgelos in die water, deur bakterieë verbruik kan word. Dit is vasgeste ${ }^{14,44}$ dat die suurstofopname weens bakteriële aktiwiteit in die water en op die dier self, in die respirasiekamer, meer as $1 \%$ van die $\mathrm{MO}_{2}$-waarde van die gemete dier kan bydra. Die aanwending van antibiotika om die bakterieë te dood, word nie aanbeveel nie, omdat dit o.a. die respirasiefisiologie van die respirerende dier kan versteur. ${ }^{44}$ Om die bydrae van die suurstofverbruikskoers deur bakterieë tot 'n dier se $\mathrm{MO}_{2}$ vas te stel, kan - binne perke - die bakterieë toegelaat word om te groei. Deur die bakterieë se suurstofverbruik apart te meet en die waarde van die totale waarde van die suurstofverbruikskoers af te trek, kan die werklike suurstofverbruikskoers van die eksperimentele dier vasgestel word.
Die manometriese metode om die $\mathrm{MO}_{2}$ van lugasemhalers vas te stel sal nog vir lank in die toekoms gebruik word. Sekerlik die belangrikste rede hiervoor is dat respirometers wat op hierdie beginsel gebou word, nie net relatief goedkoop is nie, maar deur navorsers so ontwerp kan word dat dit by die omstandighede van die dier of eksperiment kan pas. Die sirkoniumsuurstofsensor wat onlangs op die mark gekom het, sal waarskynlik in die toekoms alle ander makrorespirometers vervang om $\mathrm{MO}_{2}$ van groter invertebrate en ander lugasemhalers te meet. Die belangrike voorvereiste is dat die meetselle, wat vir soogdiere ontwerp is, kleiner gemaak moet word en dat die elektronika so aangepas word dat die $\mathrm{MO}_{2}$ van indiwiduele insekte soos miere, kewers en hulle larwes gemeet kan word. Hiermee is alreeds sukses behaal. ${ }^{46}$

Metaboliese mikrokalometrie en respirometrie ${ }^{46}$ is 'n waardevolle meettegniek as veral studies van diere gemaak word waar veranderinge in die metaboliese toestand plaasvind, byvoorbeeld: 'n dier kan van aerobiese na anaerobiese respirasie oorgaan, of herstel van anoksia. Hierdie apparatuur is baie duur en daar word veral probleme ondervind om die basislyne in langtermynmetings te stabiliseer.

Die Cartesiese duikertegniek het onlangs groot opgang gemaak, veral omdat duikers wat van perspeks vervaardig is, suksesvol gebruik is. Met hierdie moderne duikers kan die $\mathrm{MO}_{2}$ van insekte wat enkele mikrogram of milligram weeg, gemeet word.

Respirometrie van kleiner invertebrate het baie bygedra tot ons kennis van die vergelykende respirasiefisiologie van hierdie diere. Omdat $\mathrm{MO}_{2}$-metings die fundamentele biologiese prosesse weerspieël, kan hierdie meettegniek in die toekoms van nog meer nut wees, veral t.o.v. die besoedelingsbeskadiging by hierdie diere.

\section{VERWYSINGS}

1. Winterstein, H. (1912) Ein apparat zur Mikroblutgasanalyse und Mikrorespirometrie, Biochem Z., 46, 400-449.

2. Winterstein, H. (1913). Ein Mikrorespirationsapparat, Z. Biol. Technik. Methodik, 3, 246-250.

3. Umbreit, W.W., Burris, R.H. \& Stauffer, J.F. (1972). Manometric and biochemical techniques (Burgess Publ. Co. Minneapolis) P. 387.

4. Gnaiger, E. \& Forstner, H. (1983). Polographic oxygen sensors (Springer-Verlag, Berlin) P. 366.

5. Kaufmann, R., Forstner, H. \& Wieser, W. (1989). Respirometry methods and approaches. In Techniques in comparative respiratory physiology, Bridges, C.R. \& Butler, P.J. eds. (Cambridge University Press, Cambridge) P. 350.

6. Bonitati, J \& Elliot, W.B. (1971). Errors in volumetric respirometry: description of an improved microrespirometer, Anal. Biochem. , 43, 481-491

7. Kinoshita, J.H., Bunker, J.P. \& P.F. Scholander (1952). The use of the volumetric respirometer in the determination of plasma carbon dioxide, J. Lab. Clin, Med., 40, 156-160.

8. Scholander, P.F. (1949). Volumetric respirometer for aquatic animals Rev. sci. Instruments, 20, 885-887.

9. Scholander, P.F. (1950). Volumetric plastic respirometer, Rev sci. Instruments, 21, 378-380.

10. Scholander, P.F. \& Iversen, O. (1948). New design of volumetric respirometer, Scan. J: clin, Lab. Invest., 10, 429-433.

11. Scholander, P.F., Claff, C.L., Andrews, J. R. \& Wallach, D.F. (1952). Microvolumetric respirometry, J. Gen. Physiol., 35, 375-395.

12. Gilson, W.E. (1963). Differential respirometer of simplified and improved design, Science, 141, 531-532.

13. Gregory, K.F. \& Winter, H.C. (1965). Data reduction with constant pressure respirometers, Anal. Biochem., 11, 519-531.

14. Van Aardt, W.J. (1988). A Scholander-type respirometer designed for measuring both aerial and aquatic respiration, S. Afr. J. Zool., $23,37-41$.

15. Krebs, H.A. (1951). Improved manometric fluid, Biochem. J., 48 , 240-24l 
16. Scholander, P.F. (1942). Volumetric Microrespirometers, Rev. Sci, Instruments, 13, 32-33.

17. Scholander, P.F. Haugaard, N. \& Irving, L. (1943). A volumetric respirometer for aquatic animals, Rev. Sci. Instruments, 14, 48-51.

18. Caparo, V. (1953). A new method of measuring oxygen consumed in the metabolism of small animals, Nature, London 172,815

19. Turner, B.D. \& Stevenson, R.A. (1974). An electrolytic, digital reconding, multichannel micro- respirometer, J. Exp. Biol. , 61, 321-329.

20. Woodland, D.J. (1973). The ozone problem in electrolytic respirometry and its solutions, $J$. appl. ecol., 10, 661-662.

21. Linderstrom-Lang. K. (1937). Principle of the Cartesian diver applied to gasometric technique, Nature, London 140, 108.

22. Zeuthen, E. (1950). Cartesian diver respirometer, Biol. Bull., 98 , 139-143.

23. Nexo, A., Hamburger, K. \& Zeuthen, E. (1972). Simplified microgasometry with gradient divers, C.R. Trav. Carlsberg, 39, 33-63.

24. Petersen, H. (1981). Open gradient diver respirometry modified for terrestrial microarthropods, Oikos, 37, 265-274.

25. Zeuthen, E. (1964). Microgasometric Methods. Cartesian divers. In Second International Congress of Histo- and Cytochemistry. Schiebler, T.H. Pearse, A.G.E. \& Wolf, H.H. eds. (Springer-Verlag, Berlin) P. 70-80

26. Klekowski, R.Z. (1971). Cartesian diver microrespirometry for aquatic animals, Pol. Arch. Hydrobiol., 18, 93-114

27. Clark, L.C. (1959). Electrochemical device for chemical analysis, U.S. patent Z 913 356, issued Nov. 17, 1959.

28. Gnaiger, E. (1983). The twin-flow microrespirometer and simultaneous calorimetry. In Polarographic oxygen sensors, Gnaiger, E. \& Forstner, H. eds. (Springer-Verlag, Berlin)

29. Hitchman, M. (1978). Measurement of dissolved Oxygen. In Chemical Analysis, 49, P. 259. Elving. P.J. \& Winefordner, J.D. Eds. (John Wiley. New York). p. 259.

30. Hahn, C.E.W. (1974). An $\mathrm{A}_{\mathrm{g}}-\mathrm{P}_{\mathrm{b}}$ galvanic cell $\mathrm{PO}_{2}$ electrode for blood-gas analysis, J. Apl, Physiol., 37, 439-442.

31. Mackereth, F.J.H. (1964). An improved galvanic cell for determination of oxygen concentrations in fluids, J. Sci. Instrum., 41, 38-41.

32. Herreid, C.F. (1980). Hypoxia in invertebrates, Comp. Biochem Physiol., 67A, 311-320

33. Lampert, W. (1934). The measurement of respiration. In A manual on methods for the assessment of secondary productivity in Fresh Waters, Downing, J.A. \& Rigler, F.H. eds. (Blackwell, Oxford) p. 137.
34. Oertzen, J.A. von (1984). Metabolic similarity of Paleamon populations from different brackish waters. Internat. rev. des gesamten Hydrobiol., 69, 735-755.

35. Van Aardt, W.J. \& Frey, B.J. (1979). Oxygen consumption and responses of the freshwater snail Bulinus (Physopsis) globosus to gra dients of different oxygen tensions, S. A. J. Zool., 14, 202-207.

36. Van Aardt, W.J. (1990). Oxygen uptake and haemocyanin oxygen affinity of Potamonoutes Warreni calman after treamill exercise, S.A.J. Zool., 25, 11-17.

37. Atkinson, H.J. \& Smith, L (1973). An oxygen electrode microrespirometer, $J$. exp. biol. . 59, 247-253.

38. Benson, B. B. \& Krause, D. (1980). The concentration and isotopic fraction of gases dissolved in freshwater in equilibrium with the atmosphere. I Oxygen, Limnol. Oceanogr., 25. 662-671.

39. Marais, J.F.K., Akers, A.F.A. \& van der Ryst, P. (1976). Apparatus for the automatic determination of oxygen consumption in fish, Zool. Africana, 11, 87-95.

40. Scharf, E.M., Oertzen, L.A. von Scharf, W. \& Stave, A. (1981) A microflow respirometer for measuring the oxygen consumption of small aquatic organisms, Int. Rev. gesamten Hydrobiol., 66, 895-901.

41. Gnaiger, E. (1983). The twin-flow micro respirometer and simultaneous calometry. In Polarographic oxygen sensors, Gnaiger, E. \& Forstner, H. eds. (Springer-Verlag, Berlin) p. 135.

42. Van Aardt, W.J., \& Steyn, H.S. (1984). 'n Respirometer vir akwatiese diere, ge-yk teen die Scholander-respirometer, S. A. Tydskr. Natuurwet. Tegnol., 3, 204-206.

43. Cameron, J.N. (1986). Principles of physiological measurement (Academic Press, New York).

44. Dalla Via (1983). Bacterial growth and antibiotics in animal respirometry. In Polarographic oxygen sensors, Gnaiger, E. \& Gorstner, H. eds. (Springer-Verlag. Heidelberg) P. 203.

45. Du Preez, H.H., Strydom, W. \& Winter, P.E.D. (1986). Oxygen consumption of two marine teleosts, Lithognathus mormyrus (Linnaeus, 1758) and Lithognathus lithognathus (Cuvier, 1830) (Teleosti: Sparidae), Comp. Biochem, Physiol., 85A, 313-331.

46. Lighton, J.R.B., Bartholomew, G.A. \& Feener, D.H. (1987). Energetics of locomotion and load carriage and a model of the energy cost of foraging in the leaf-cutting ant Atta colombica Guer., Physiol. Zool., 60, 524-537. 